9,1\% у жінок), з інсультом - жінки (9,2 проти 6,4\%).

Середній вік пацієнтів першої групи на час дослідження становив 59,4 року проти 64,7 року В другій групі та 62,4 року в третій групі хворих. Не зареєстровано жодного пацієнта віком до 40 років у другій та третій групах, а мінімальний вік у першій групі більш ніж удвічі нижчий за аналогічний показник у другій та третій групах (20 років проти 43-48 років).

Частка пацієнтів з соціально незахищених верств населення у першій групі становить 71,4\%, у другій та третій групах цей показник перевищує $80 \%$ $(81,1$ та $82,6 \%$ відповідно), найвище у жінок по всіх трьох групах $(81,2 ; 86,5$ та 87,8\% відповідно). Більшість хворих по всіх трьох групах проживає у містах-мегаполісах $(60,8 \%)$, а також у депресивних у соціально-економічному плані регіонах $(21,8 \%)$ та на підконтрольній території окупованих регіонів (4,9\%). Повторний IM було зареєстровано у $3 \%$ хворих на ЦД, особливо у жінок (3,4\% проти 2,7\% у чоловіків). Більш ніж утричі частіше за повторний IM траплявся повторний інсульт $(9,7 \%)$, удвічі частіше у жінок (12,2\% проти 6,2\% у чоловіків). Частка хворих на IM серед хворих на інсульт удвічі вища за аналогічний показник серед усіх хворих на ЦД $(20,7$ та $10,1 \%$ відповідно), насамперед за рахунок чоловіків (33,9 проти $10,9 \%$ серед усіх пацієнтів), частота IМ у жінок третьої групи незначно більше за такий показник по першій групі - 11,1 та 9,1\% відповідно. Частка хворих на інсульт серед пацієнтів з ЦД та ІМ удвічі більше за аналогічний показник серед усіх хворих на ЦД (15,5 проти 7,8\% відповідно), утричі частіше у чоловіків (17,9 проти 6,4\% відповідно), незначно більше у жінок (12,5 та 9,2\% відповідно). Середній рівень глікованого гемоглобіну по всіх трьох групах фактично на одному рівні (у першій групі - 9,0, другій групі - 9,1, третій групі - 8,9) та відповідає декомпенсації ЦД, найбільше у жінок по трьох групах (9,2; 9,3 та 9,1 відповідно).

Висновки. Встановлено суттєві відмінності між частотою ЦД і частотою IM та інсульту у цих хворих залежно від статі пацієнта. Середній вік хворих на ЦД з ІМ та інсультом та середня тривалість захворювання на ЦД вищі порівняно з загальною популяцією хворих на ЦД. Переважну більшість становлять соціально-незахищені верстви населення. Повторні захворювання на IM та інсульт у хворих на ЦД частіше у жінок. Частота перехресних захворювань (ІМ у хворих на ЦД та інсульт, інсульт у хворих на ЦД та IM) удвічі перевищує показники частоти IM та інсульту серед хворих на ЦД, втричі частіше у чоловіків.

Ключові слова: цукровий діабет, інсульт, інфаркт, особливості перебігу.

\section{ЛITЕРАТУРА}

1. International Diabetes Federation. IDF Diabetes Atlas, 8th ed. Brussels: IDF, 2017.

2. Introduction: Standards of Medical Care in Diabetes - 2018. Diabetes Care. 2018; 41(Suppl. 1):S1-S2. doi: $10.2337 / \mathrm{dc} 18-$ Sint01.

3. Zheng Y, Ley $S H, H u F B$. Global aetiology and epidemiology of type 2 diabetes mellitus and its complications. Nat Rev Endocrinol. 2018 Feb;14(2):88-98. doi: 10.1038/nrendo.2017.151.

Дата надходження до редакції 23.10.2018 p.

https://doi.org/10.24026/1818-1384.4(64).2018.150178

\title{
АНАЛІЗ 22-РІЧНОГО ДОСВІТУ ХІРУРГІЧНОГО ЛІКУВАННЯ ПУХЛИН НАДНИРКОВИХ ЗАЛОЗ В УМОВАХ СПЕЦІАЛЗОВАНОГО ЕНДОКРИНОЛОГІЧНОГО ЦЕНТРУ
}

\author{
М.В. Кунатовський, О.А. Товкай, С.О. Тарасенко, О.О. Сфімова \\ Украйнський науково-практичний иентр ендокринної хірургії, трансплантаиї \\ ендокринних органів і тканин МОЗ України
}

Вступ. Хірургія надниркових залоз (Н3) завжди вважалася одним із найбільш ризикованих і технічно складних втручань через поєднання особливих топографо-анатомічних умов, необхідності виконання великого й травматичного операційного доступу незалежно від його виду (лапаротомічного, люмботомічного, торако-люмботомічного), власної структури органа, наявності у багатьох пацієнтів ендокринних системних змін, що створюють додаткові перешкоди. Розвиток нових хірургічних 
технологійдозволивсуттєвимчиномзмінитипідходи до хірургічного лікування патології Н3 починаючи 3 1990-х років, коли було розроблено загальні засади виконання лапароскопічних адреналектомій (ЛА), перше повідомлення про які з'явилося 1992 року. Починаючи з 2000 року, ЛА визнано «золотим стандартом» для лікування доброякісних пухлин і пухлин розміром менше 6-8 см. Ендоскопічна (трансперитонеальна або ретроперитонеальна) операція, за даними численних повідомлень, має значну перевагу перед відкритими втручаннями в аспекті швидкості відновлення нормальних функцій, менших травматизму та крововтрати, меншого больового синдрому та ліпших косметичних наслідків.

Мета: проаналізувати дані 22-річного досвіту спеціалізованого ендокринологічного центру хірургічного лікування пухлин Н3.

Матеріали та методи. Проаналізовані історії хвороби, перебіг периопераційного періоду у 1256 пацієнтів з пухлинами Н3, у тому числі 255 осіб 3 феохромоцитомою, яким виконані адреналектомії за період 1995-2017 років в УНПЦЕХТЕОіТ. Середні дані наведені в форматі $\mathrm{M} \pm \sigma$.

Результати та обговорення. При аналізі оперативного доступу відмічено, що 31256 операцій на Н3 255 (20,3\%) було виконано відкритим, лапаротомічним чи люмболапаротомічним доступом, а 1001 (79,7\%) операція - методом ЛА. У пацієнтів з феохромоцитомою Н381 (31,8\%) операція на Н3 була виконана відкритим, лапаротомічним чи люмболапаротомічним доступом, а 174 (68,2\%) операцій - методом ЛА. За гендерним показником чоловіків було 334 (26,6\%), жінок - 922 (73,4\%), а серед пацієнтів 3 феохромоцитомою Н3 - 80 (31,4\%) чоловіків, 175 (68,6\%) жінок. Середній вік прооперованих на Н3 дорослих пацієнтів становив 47,7士14,6 року. Середня крововтрата при

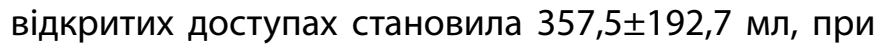
ЛА - 42,2士31,6 мл (достовірна різниця ( $<<0,05)$ за критерієм Уілкоксона). Тотальна внутрішньовенна анестезія при відкритих методах застосована була в 93,3\%, а при ЛА в 73,0\% пацієнтів. Сучасна мультимодальна анестезія на основі інгаляційного анестетика севофлурану була застосована при відкритих операціях та ЛА в 6,7\% та 27,0\% випадків відповідно (достовірна різниця $(\mathrm{p}<0,05)$ за критерієм X-квадрат Пірсона). Тривалість втручання становила $130,3 \pm 46,9$ хв. та 63,1 $\pm 19,2$ хв. при відкритих операціях та ЛА відповідно (достовірна різниця, p <0,05). Тривалість стаціонарного перебування при ЛА становила 7,3 44,9 доби, при відкритих доступах - 12,3土6,9 доби (достовірна різниця, $p$ $<0,05)$. Застосування наркотичних анальгетиків при відкритих доступах тривало в середньому

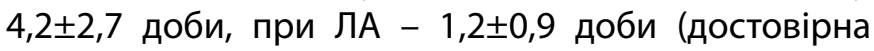
різниця, $p<0,05)$. Середня доза морфіну становила при відкритих втручаннях 94,5+41,3 мг, при ЛА -

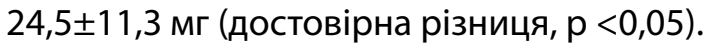

Висновки. Таким чином, впровадження лапароскопічних методів хірургічного втручання при пухлинах надниркових залоз сприяє швидшому відновленню пацієнтів, скороченню періоду перебування в стаціонарі, супроводжуються меншою крововтратою, менш виразним больовим синдромом.

Ключові слова: пухлини надниркових залоз, адреналектомія, загальна анестезія.

\section{ЛІТЕРАТУРА}

1. Conzo G, Pasquali D, Della Pietra C, et al. Laparoscopic adrenal surgery: ten-year experience in a single institution. BMC Surg. 2013; 13(Suppl 2): S5.

2. Павловський М.П. 50-річний досвід діагностики та лікування хворих із пухлинами надниркових залоз / М.П. Павловський, Н.І. Бойко, Я.І. Гаврик // Клінічна ендокринологія та ендокринна хірургія. - 2008. - № 3(24). - C. 31-34. DOI: https://doi. org/10.24026/1818-1384.3(24).2008.118470.

3. Черенько С.М. Лапароскопічна адреналектомія: досвід перших 300 операцій у клініці ендокринної хірургії / С.М. Черенько, О.С. Ларін // Клінічна ендокринологія та ендокринна хірургія. - 2010. - № 3(32). - C. 3-8. DOl: https://doi. org/10.24026/1818-1384.3(32).2010.96396.

Дата надходження до редакції 24.10.2018 p. 